\title{
Koerner, András. 2018. Jewish Cuisine in Hungary - A Cultural History with 83 Authentic Recipes. Budapest: Corvina and Central European University CEU Press. 420 pp. Illus.
}

\author{
Reviewed by Ilana Rosen, ${ }^{*}$ Ben Gurion University of the Negev
}

András Koerner's Jewish Cuisine in Hungary is a comprehensive account, including many visual images, of the foodways of Hungarian Jews from the mid nineteenth-century until 1945. The present English edition is a translation of Koerner's/Körner's A Magyar zsidó kunyha: kultúrtörténet 77 autentikus recepttel (Budapest: Corvina, 2017). In its scope this work is related to Koerner's previous publication, likewise by the Central European University Press, How They Lived - the Everyday Life of Hungarian Jews 1867-1949, published in two volumes (2015, 2016). Koerner is an architect who was born in Budapest in 1940 and who since 1967 lives in the United Sates. Following his retirement, Koerner has devoted his time to writing and curating exhibitions about Hungarian-Jewish everyday life in the last two centuries, including HungarianJewish cookbooks and other gastronomical products and practices.

After a Preface by Barbara Kirshenblatt-Gimblett, a New-York University expert on Jewish studies, the book's Introduction opens with a zoom-in on a Seder (Passover Holiday) dinner at the house of the Stern family of Dob Street in Budapest, around 1940. This family's dinner table illustrates that even within one (extended) Orthodox Jewish family there are diverse customs deriving from the different backgrounds of the family's members, in this case the womenfolk, the ones who actually cook. Women of Galician background in this family prepared gefilte [Yid. 'stuffed'] fish, ground fish balls, to avoid possible transgression of the prohibition on borer (Heb. sorting out or cleansing) when removing fish bones from one's course, which is forbidden on Shabbat/Saturday and high holidays. By contrast, women of Hungarian or Westerly background in the same family might prepare and serve a whole fish, because in their home communities the conception of borer excludes the act of clearing fish bones from one's course. As in this instance, throughout his book Koerner will demonstrate that in the case of Hungarian Jews, as probably in that of other Jewish groups, cultural identities and processes are actually more strongly, vividly and immediately felt in a family's kitchen than in its Synagogue.

In Chapter One, devoted to "Kashrut," the author explicates the religious laws and practices of preparing food according to the Torah and its later interpretations. This chapter surveys the ritual slaughter of kosher animals such as chicken, geese and cattle; the koshering of meat following the slaughter; the strict rules for separating fleshy and dairy products during their preparation, serving, and eating; the category of pareve [Yid. 'neutral'] (25), meaning neither

*ilanaro@bgu.ac.il

$($ (c) $)$ EY

ULIS D-Sorke
New articles in this journal are licensed under a Creative Commons Attribution 4.0 International License.

This journal is published by the University Library System of the University of Pittsburgh as part of its D-Scribe Digital Publishing Program and is cosponsored by the University of Pittsburgh Press 
Rosen, Ilana. "Koerner, András. 2018. Jewish Cuisine in Hungary - A Cultural History with 83 Authentic Recipes. Budapest: Corvina and Central European University CEU Press. 420 pp. Illus." Hungarian Cultural Studies. eJournal of the American Hungarian Educators Association, Volume 13 (2020) DOI: 10.5195/ahea.2020.407

fleshy nor dairy, like vegetable and fruit; and the production of kosher wine. This chapter also traces the process of secularization in the period under examination, a time when the Jews of Hungary and Central Europe gradually became alienated to their olden-days ethos and foodways yet remained partly still attached to their once-was tastes, as will be exemplified in the third chapter.

Ch. 2, "Ashkenazi Jewish Cuisine," introduces and defines Ashkenazi Jews, a group that originally included the Jews of Germany, Northern France and Austria, and which later came to encompass all Jews living in Western, Central and Eastern Europe. The author lists the kinds of food and dishes typical of the Ashkenazi kitchen, e.g.: "Noodle courses, thick soups, legumes, cabbage, fish, meat and bread" (42). To complete the picture of the two main groups of Jews worldwide, Ch. 3, "Hungarian Jewish Cuisine," discusses the Sephardic (Spanish-Jewish) influence on Hungarian-Jewish cooking, such as the use of goat meat and mutton brought into Hungary during the period of the Ottoman rule (1526-1686) by Jews moving into the country from the Ottoman Empire's other parts. For example, reading the chronicle of a Buda resident by the name of Isaac Schulhof, of 1686, just before the siege that eventually ended the Ottoman rule in the country, one might be impressed by the affluence of food and products surrounding this author. Following this record, Koerner tells us, there is a gap of some hundred and fifty years, until the mid-nineteenth-century, in any sources about Hungarian-Jewish foodways. Toward the end of this chapter he makes the telling point that Jewish taste in food was something that remained with the country's Jews even long after their desertion of religious observation, and it could be expressed by stresses of certain ingredients or choices of seasoning. An example for both is the tendency to sweeten dishes, other than just desserts and pastries, which may have been the habit of Polish Jews who used vinegar for preserving holiday dishes that had to be put aside until they were served, and, to negate their sour taste, they added sugar to them. Sweetening may have also been connected to Rosh Hashana [lit. 'The Head of the Year'], the Jewish New Year, in which sweetness symbolizes hope for a better, "sweeter" new year; and fish-head, rosh-dug, likewise marks a new beginning, as in Rosh Hashana.

Ch. 4 deals with "Regional and Cultural Differences" or actually with regional influences on the Hungarian-Jewish cuisine. For example, gefilte fish, mentioned in the book's Introduction, is a dish that has wandered into Hungary from Eastern-European Jewish communities; yet, it has not, despite its general popularity among all Ashkenazi Jews, been adopted into the Jewish cuisine of the country's western parts. Another so-called Eastern-European import is foods made of corn-flour, mainly porridges. As for Western influences, the very fact that the first Hungarian cookbooks were written in German attests to the dominance of this language and culture. In addition, the Hungarian and Hungarian-Jewish cuisines have absorbed some tastes and influences from Romania, the Balkan Peninsula, and the Ottomans. The eggplant vegetable, or actually fruit by Koerner (135), is a central example among these influences. The author discusses this food's exoticism, to the point that Margit Vészi, a writer of Jewish origin and the first wife of writer Ferenc Molnár, was not at all familiar with its Hungarian name of padlizsán and instead called it by its French name of Aubergine.

Ch. 5, "Weekdays and Holidays," covers year-cycle and life-cycle celebrations as expressed in the lives and plates of Hungarian Jews, and in it Koerner surveys weekday and Shabbat dishes as well as those prepared for the Jewish holidays. He also pays special attention to cakes and sweets prepared for significant stages in the lives of Jewish boys and young men as 
Rosen, Ilana. "Koerner, András. 2018. Jewish Cuisine in Hungary - A Cultural History with 83 Authentic Recipes. Budapest: Corvina and Central European University CEU Press. 420 pp. Illus." Hungarian Cultural Studies. eJournal of the American Hungarian Educators Association, Volume 13 (2020) DOI: 10.5195/ahea.2020.407

they progress into the world of religious learning and proper conduct. The author surveys the festive foods prepared for a baby boy's Brit Milah (circumcision) ceremony, for a three-year old's starting to learn in the $c /$ heder (traditional school for boys in the ages of three to thirteen), for a boy's first exam in the c/heder, and for his Bar Mitzva marking his turning into a man at the age of thirteen. Curiously, even though the author does point out that Jews also celebrate the first day of each Jewish/Hebrew month in their (lunar) calendar (158), he fails to note that by tradition the "Head of the Month" is a women's holiday. This is so first because of the moon's growing and diminishing that symbolize the feminine recreation cycle, and second because by tradition, soon after the Exodus, the newly-freed Israelite women refused to hand in their gold jewelry for the creation of the Golden Calf, the making of which was a sin of idolatry.

Chapter 6, "Households," despite its title, takes the readers out of the houses and kitchens of Jewish families to a journey of sorts to the outdoor places where their food was grown, excluding livestock (which was dealt with in Ch. 1 addressing kashrut). This chapter first visits rural and small-town households, in which the families lived off their vegetable gardens, and then city markets and stores, where people obtained those products that their rural brethren grew by their homes. This chapter also discusses Jewish women and their central role in the household, as well as both Jewish and non-Jewish maids of mostly poor and low status employed by Jewish families, often living with them for years or even decades and never starting their own families. Sometimes, after years of service, a gentile maid would become so knowledgeable in the family's religious life that she might even feel and be perceived by them as one of the family. Finally, this chapter features, both verbally and pictorially, tools and products of religiousobservant families, kitchens and dining rooms with their furniture, tableware, tablecloths and ritual artifacts.

Ch. 7, "Domestic Hospitality and Banquets," explores the Jewish social life and festive occasions as reflected by the community's food customs. For example, the author describes the routine of "day/s eating" (Yid. teg essen, more often using the plural and not the singular tog, as on p. 237), by which poor yeshiva-students were regularly hosted by better-off Jewish families. Koerner also examines some instruction books on Illem or good-manners, a genre partly deriving from Talmudic teachings of the eighth and ninth centuries and partly influenced by late nineteenth-century European norms. This genre was of need among secularizing Jews making their first strides outside their familiar surroundings. In Koerner's words: "Traditional Jews mainly stressed the importance of daily study of the Torah and the necessity of observing many religious rules..., and they placed less emphasis on well-mannered behavior that was in accord with the expectations of society, including the majority society's customs and conventions related to meals" (254). Hence the growing need for and interest in these writings of etiquettes.

Ch. 8 introduces "Jewish Places of Hospitality" such as kosher restaurants and boarding houses, coffee houses, coffee shops, pastry shops and soup kitchens for the poor. In this chapter as, in fact, throughout the entire book, the author does not differentiate between dwellers of the country's capital of Budapest and those of more remote areas that are often referred to as vidék meaning far-away provinces or countryside. Rather, his movement from one site of hospitality to another is determined by the theme of travel as described in the diaries and chronicles he explores. This way images of Jewish boarding houses and restaurants in Pest, Buda, Mezölaborc (presently in Slovakia) or Csepreg in Western Hungary are all juxtaposed as locales existing on the same par, due to their function of accommodation, notwithstanding their very different 
Rosen, Ilana. "Koerner, András. 2018. Jewish Cuisine in Hungary - A Cultural History with 83 Authentic Recipes. Budapest: Corvina and Central European University CEU Press. 420 pp. Illus." Hungarian Cultural Studies. eJournal of the American Hungarian Educators Association, Volume 13 (2020) DOI: 10.5195/ahea.2020.407

locations and characteristics (260-263, 270-271,273). This chapter ends with Jewish soup kitchens, an institution of charity offering a daily hot meal to poor, beggar or travelling people, which was (and in many present-day poor and/or Orthodox communities still is) one of several institutions of socio-economic support.

Ch. 9, "Food Industry and Trade," surveys Jewish kosher food-factories and wineries, as well as shops, markets, and street vendors. In this chapter that partly overlaps with some sections of chapters 1 and 8, the author again marvels at the phenomenon of secularized Jews or formerJews still or ever cherishing kosher food. Ch. 10, "Characteristic Dishes," recounts the stories behind some of the most typical dishes of traditional or tradition-lover Jews, such as cholent, kugel, matzo balls and more. Here these dishes are featured as Jewish-cuisine specialties appealing also to non-Jewish every-diners. Finally, the book has several detailed appendices and indices including an annotated bibliography of the thirteen Jewish cookbooks published in Hungary until 1945, a full listing of the thirty-three hand-written recipe collections the author has obtained for his project, a list of almost one hundred recipes, many of which have been briefly referred to in the course of the book, as well as several other source and apparatus parts. Besides all these, as noted, András Koener's Jewish Cuisine in Hungary is richly illustrated with many photos and other reproductions of material-culture artifacts and symbols that together turn this book into a lively tour-guide of sorts to the culinary ethos of predominantly nineteenth-century Hungarian and Central-European secularizing/ed Jews. 